Cakrawala Dini: Jurnal Pendidikan Anak Usia Dini | p-ISSN 2087-I317 | e-ISSN 2621-8321 Vol. II. No.I Mei 2020 | Hal 37-50

\title{
MANAJEMEN PENDIDIK BERBASIS KEARIFAN LOKAL
}

\author{
Fu'ad Arif Noor ${ }^{1}$ \\ ${ }^{1}$ Sekolah Tinggi Pendidikan Islam (STPI) Bina Insan Mulia Yogyakarta
}

\begin{abstract}
This study explains the management of educators based on Indonesian local wisdom or culture, especially in Yogyakarta, which teaches students to be attached to real situations and condition that they face. The pillars of local wisdom educators namely: 1) growing educated people based on the recognition of the existence of personality before born, 2) education based on the truth and virtue (Akhlak Mahmudah), avoiding ways of thinking that are false and gratuous or sulaton waton (problematic), 3) education that delivers moral, spiritual (affective domain) domains, as well as being able to internalize body and soul, not merely cognitive or psychomotor domains, and 4) synergize with culture, education and tourism which are very needed to be developed in synergized in character education.
\end{abstract}

Keywords: Management, Educators, Local wisdom.

\begin{abstract}
Abstrak: Kajian ini untuk menjelaskan perihal manajemen pendidik yang berbasis kepada kearifan atau budaya lokal Indonesia khususnya berada di Yogyakarta yang mengajarkan anak didik agar lekat terhadap situasi maupun kondisi nyata yang dihadapinya. Pilar pendidik kearifan lokal berupa: 1) menumbuhkan manusia berpendidikan yang berlandaskan pada pengakuan eksistensi keperibadian sejak dalam rahim, 2) pendidikan yang berbasis nilai kebenaran serta keluhuran budi (Akhlak Mahmudah), terhindar dari cara berpikir yang kurang benar dan grusa-grusu (tergesa-gesa) atau waton sulaya (asal bermasalah), 3) pendidikan yang menghantarkan ranah moral, spiritual (ranah afektif), sekaligus mampu menginternalisasi pada jiwa raga, bukan sekedar kognitif maupun ranah psikomotorik, dan 4) bersinergi terhadap kebudayaan, pendidikan maupun pariwisata yang sangat perlu dikembangkan secara bersinergi dalam pendidikan yang berkarakter.
\end{abstract}

Kata Kunci: Manajemen, Pendidik, Kearifan Lokal.

'Sekolah Tinggi Pendidikan Islam (STPI) Bina Insan Mulia Yogyakarta, Email: fuad.arif.nour国gmail.com 


\section{PENDAHULUAN}

Kearifan lokal menjadi salah satu bagian konstruksi kebudayaaan atau budaya lokal. Kearifan lokal mengarah kepada keaneka ragam kekayaan budaya yang berkembang dan tumbuh dalam lingkungan masyarakat yang dikenal, dan dipercayai serta diakui sebagai komponen penting yang siap memperkuat kohesi sosial antar warga masyarakat. Kearifan lokal masih didominasi oleh beragam nilai adat sebagaimana sebuah kelompok sosial menjalankan prinsip-prinsip manajemen, konservasi dan eksploitasi sumber daya alam sekitar. Perwujudan dari bentuk kearifan lokal yang merupakan pencerminan dari sistem pengetahuan yang berasal pada nilai budaya di berbagai daerah belahan Indonesia, nilai budaya ada yang tenggelam dari ingatan komunitas. Tetapi, di sebagian komunitas tersebut walaupun sudah tidak lengkap lagi atau telah berakulturasi dengan perubahan baru mengikuti perkembangan jaman dari luar, masih tampak ciri-ciri khusus atau khasnya yang masih berfungsi sebagai pedoman hidup bermasyarakat.

Pendidik dalam melaksanakan pembelajarannya berusaha untuk memanfaatkan berbagai nilai kearifan atau budaya lokal sebagai sumber bahan pembelajaran untuk anak didik. Berbagai nilai dalam kearifan lokal yang dimiliki oleh daerah sekitar lembaga atau sekolah dan anak didik diintegrasikan dalam proses pembelajaran. Menurut Poespowardojo yang dikutip dalam bukunya Rahyono (2009, p. 9), kearifan lokal (local genius) mempunyai ketahanan terhadap berbagai hal dari luar serta mampu berkembang di masa mendatang. Kepribadian dari masyarakat yang ditentukan oleh kemampuan local genius dan kekuatan dalam menghadapi dari luar tersebut. Jika local genius musnah atau hilang, maka kepribadian suatu bangsa juga akan menjadi pudar. Berbagai faktor yang mampu menjadikan pembelajaran dan pengembangan kearifan lokal punya posisi yang strategis adalah: 1) Kearifan lokal mampu merubah identitas yang inheren semenjak lahir, 2) bukan sekedar keasingan atau kekhasan bagi pemiliknya, 3) keikutsertaan emosional masyarakat dalam penghayatan dan menjalankan kearifan lokal sangat kuat, 4) pembelajaran kearifan lokal tidak membutuhkan paksaaan, 5) dapat menumbuhkan kepercayaan diri dan harga diri, 6) bisa meningkatkan harkat serta martabat Bangsa maupun Negara.

Kearifan lokal dapat menjadi bagian budaya dari masyarakat yang tidak dapat terpisah dengan bahasa masyarakatnya. Local wisdom (Kearifan lokal) sering diwariskan nenek moyang secara turun temurun, berikutnya dengan cerita lisan ke lisan. Keberadaannya dalam peribahasa, cerita rakyat, lagu, maupun permainan rakyat, sebagai suatu pengetahuan, ditemukan dalam masyarakat terebut melalui kumpulan pengalaman dalam mengintgrasikan dan mencoba dalam pemahaman terhadap budaya maupun kondisi alam suatu tempat di masyarakat tersebut. Menurut Padmanugraha (2010, p. 12). Kearifan lokal bisa menjadi bagian budaya dari masyarakat yang sulit dipisahkan dari bahasa masyarakatnya. Biasanya diwariskan secara berkelanjutan dari nenek moyang turun temurun yang selanjutnya dengan cerita mulut ke mulut.

Manajemen pendidik yang lemah dalam mendorong pembaruan pendidikan dan membangun manusia seutuhnya akan menjadikan jabatan guru tidak lagi terhormat di masyarakat. Kondisi guru yang lemah secara profesional maupun gaji finansial, apalagi semenjak orde baru, para guru menerima represi dan eksploitasi dari penguasa melalui berbagai politisasi dan regulasi yang tidak menguntungkan. Akibatnya para guru kurang memperoleh penghargaan 
yang manusiawi dan wajar (Arif Rohman, 2009, p. 193).

Manajemen pendidik bertujuan untuk memberdayakan guru secara efektif serta efisien untuk memperoleh dengan hasil yang optimal, tetapi tetap terkondisi menyenangkan. Sehubungan hal tersebut, fungsi personalia yang dilaksanakan pimpinan yaitu: mengembangkan, menggaji, menarik, lalu memotivasi personil untuk mencapai tujuan sistem, membantu anggotanya mencapai standar perilaku dan posisi, menyelaraskan tujuan individu maupun organisasi, serta mengoptimalkan perkembangan karir guru atau tenaga kependidikan. Manajemen guru atau personil meliputi; pengadaan, perencanaan, pembinaan atau pengembangan, promosi ataupun mutasi, kompensasi, dan pemberhentian, serta penilaian. Semuanya dilakukan dengan benar dan baik agar apa yang diinginkan tercapai, yaitu tersedianya tenaga kependidikan atau guru yang dibutuhkan dengan kemampuan dan kualifikasi sesuai serta dapat melakukan tugasnya dengan berkualitas dan baik (Fachruddin dan Ali Idrus, 2011, p. 145).

\section{TINJUAN PUSTAKA}

Penelitian-penelitian terdahulu dapat ditemukan beberapa kajian berdasarkan klasifikasi tematik, yaitu: Penelitian Farida Rahmawati yang berjudul "Manajemen Guru Pendidikan Islam Sekolah Dasar (Studi Kasus Kelompok KKG PAI SD di Juwiring kabupaten Klaten), penelitiannya menyimpulkan bahwa manajemen guru yang dilaksanakan melalui empat proses, yaitu pertama proses perencanaan meliputi; kegiatan rutin KKG di kecamatan dan kabupaten, program pelatihan, kegiatan lomba MAPSI dan MTQ, kedua proses pengorganisasian terdapat suatu kepengurusan yang tampak jelas dikendalikan oleh ketua dan pengurus lainnya, ketiga proses pelaksanaan dimana kegiatan KKG diadakan setiap seminggu sekali, dan terakhir proses keempat adalah pengawasan dengan tujuan membuat segenap kegiatan manajemen guru (Farida Rahmawati, 2012).

Terkait perihal kinerja pendidik dalam pembelajaran kearifan lokal, penelitian Nurul Ashlihah yang berjudul "Manajemen Guru dalam Pengelolaan Kelas Satu SD Muhammadiyah Wonogiri Tahun Pelajaran 2015/2016", Hasil penelitiannya adalah: Manajemen guru di SD Muhammadiyah Wonogiri dalam pengelolaan kelas satu oleh guru kelas 1A dan 1B yang telah dilaksanakan diawali dari perencanaan, kemudian pengorganisasian, selanjutnya pengarahan, dan diakhiri dengan pengawasan, serta yang membedakan adalah di kelas satu lebih berat karena ditambah dengan sarapan pagi (sargi), tadarus dan BTQ. Mengenai karakteristik peserta didik yang masih sulit di kelas rendah untuk difokuskan atau diarahkan pada aktivitas pembelajaran. (Nurul Ashlihah, 2016).

Penelitian yang terungkap di atas hanya beberapa kecil saja yang terkait langsung dengan tema penelitian yang dilaksanakan, dan masih banyak penelitian lagi yang membahas tentang guru. Temuan penelitian terdahulu adalah referensi yang sangat bermakna, sebagai benang merah bagi penelitian yang dilakukan. Oleh sebab itu hasilnya dapat disimpulkan secara substantif, bahwa hampir semua penelitian menyebutkan profesionalitas guru, sosok guru yang ideal, perilakunya, moralitasnya, nilai-nilai kehidupan dan sebagian manajemen guru pendidikan Islam, manajemen SDM dan manajemen pendidik maupun tenaga kependidikan.

Jurnal-jurnal dari hasil penelitian di atas membuktikan sebagian kecil yang membahas tentang guru teladan, dan semuanya membahas tentang manajemen pendidikan, profesionalitas, moralitas, dan kepribadian, demikian pula dengan penelitian terdahulu ditemukan setiap 
penelitian membahas fokusnya masingmasing, dengan pendekatan yang berbeda-beda. Dari beberapa referensi di atas tertangkap kesimpulan bahwa semua penelitian terdahulu membahas tentang guru, madrasah, moralitas, keteladanan, manajemen, kompetensi, profesional, guru yang ideal, kesemuanya membahas idealisme seorang guru.

\section{METODOLOGI PENELITIAN}

Pendekatan penelitian ini adalah kualitatif dengan menggunakan metode deskriptif. Data kualitatif yang diperoleh dari hasil penelitian dapat dijadikan sebagai sumber dari deskriptif yang luas dan berlandasan pendapat kokoh, juga mengandung penjelasan perihal semua proses yang terjadi di lingkungan setempat. Data yang diambil secara kualitatif mampu memahami dan mengikuti peristiwa secara kronologis, mengukur sebab maupun akibat dalam ruang lingkup pendapat orang-orang di sekitarnya. Penelitian jenis ini sesuai untuk meneliti kondisi objektif subjek peneliti sehingga pendekatan dan prosedur yang berlangsung dari luar maupun dari dalam menjadi bagian penelitian kualitatif yang berlangsung sebagaimana mestinya.

Pengumpulan datanya melalui observasi, wawancara, angket dan dokumentasi. Menurut pendapat Bogdan dan juga Biklen (Moleong, 2007, p. 248), bahwa analisis datanya merupakan upaya yang dilakukan melalui cara kerja data, kemudian mengorganisasikan, memilah dan memilih datanya menjadi satu kesatuan yang bisa diatur, untuk mencari serta menemukan pola, mensintesiskannya, menemukan perihal yang penting dan dipelajari, sekaligus memutuskan hal yang dapat diberlakukan untuk orang lain. Secara sederhana teknik analisis data penelitian ini mencakup tiga tahap yaitu mereduksi data, menyajikan data, dan diakhiri dengan penarikan kesimpulan.

\section{HASIL PENELITIAN DAN PEMBAHASAN}

Kearifan bermula dari kata arif. Arif mempunyai dua arti, pertama tahu atau mengetahui. Kedua berarti cerdik, pandai serta bijaksana (Kamus, 2006, p.105). Kemudian kata arif memperoleh awalan ke- dan akhiran -an menjadi kearifan bermakna kecendekiaan, kebijaksanaan, sebagai sesuatu yang diperlukan dalam berinteraksi.

Berikutnya ketika digabung dengan kata lokal, yang berarti tempat atau pada suatu tempat, atau pada suatu tempat yang tumbuh, terdapat, hidup sesuatu yang mungkin berbeda halnya dengan tempat yang lain, atau di suatu tempat bernilai yang berlaku setempat atau juga berlaku secara universal (Fahmal, 2006). Kearifan lokal secara keseluruhan berarti sebagai kearifan berupa kebudayaan tradisional terhadap suku-suku bangsa. Kearifan lokal dalam makna yang luas bukan sekedar berupa norma-norma dan nilai-nilai budaya, tetapi juga segala bentuk gagasan, termasuk yang terkait implementasinya terhadap teknologi, penanganan kesehatan, dan estetika. Dengan pengertian tersebut, jadi yang tergolong sebagai penjabaran kearifan lokal, yaitu berbagai bentuk tindakan serta hasil budaya material daerah setempat.

Pengartian kearifan lokal yang luas tersebut berada menyebar dalam segala warisan budaya, baik bersifat intangible maupun yang tangible (Edy Sedyawati, 2006). Wacana terhadap seputar local wisdoms atau biasa dikenal dengan kearifan lokal, biasanya selalu disandingkan dengan wacana revolusi atau perubahan, modernisasi, bahkan relevansinya. Pada sisi yang lain terdapat ekspresi kearifan lokal juga dituntut agar 
mampu merespons berbagai perubahan nilai dalam masyarakat.

Kearifan lokal dari sebuah masyarakat itu tidak ingin hilang dari peredaran nilai, karenanya didefinisikan sebagai niali-nilai atau kebijaksanaan luhur yang tertanam dalam aneka ragam kekayaan budaya lokal yang berupa: petatah-petitih, tradisi, serta semboyan hidup (Nasiwan, 2012). Menurutnya kearifan lokal terdapat dua perspektif yang saling bertentangan atau bertolak belakang. Dua perspektif tersebut adalah pertama extreme acculturation, dan yang kedua perspektif a less extreme, extreme acculturation yaitu memperlihatkan berbagai bentuk tiruan suatu budaya yang proses evolusinya tidak ada, sehingga memusnahkan aneka bentuk budaya tradisional. Sedangkan Less extreme acculturation itu proses akulturasi yang tetap menyisakan serta memperlihatkan local genius apa adanya, berarti adanya ciri-ciri atau unsur-unsur tradisional yang akan bertahan dan sekaligus mempunyai kekuatan untuk mengakomodasikan berbagai unsur budaya dari luar serta mengintegrasikan kebudayaan aslinya.

Nilai-nilai dalam kearifan lokal diharapkan mampu memegang pengendalian diri serta memberikan arah terhadap perkembangan kebudayaan, sekaligus menjadi manifestasi kepribadian yang melekat dari suatu masyarakat tersebut. Artinya identitas suatu masyarakat tercermin dalam arah yang menunjukkan kepada pandangan hidup dengan sistem nilainya, dalam pola maupun sikap perilaku hidup yang terlihat dalam tingkah laku keseharian, juga dalam gaya hidup tercermin perilaku hidupnya. Kedudukan lokal genius tersebut signifikan dalam konteks eksistensi terhadap kebudayaan dari warga masyarakat atau suatu kelompok. Hal ini menjadi kekuatan yang mampu tetap bertahan terhadap berbagai unsur yang datangnya dari luar dan mampu juga berkembang untuk masa-masa yang mendatang. Pudar bahkan hilangnya local genius, berarti pula hilang dan memudarnya kepribadian dari suatu masyarakat tersebut, sedang kekal kuatnya local genius agar berkembang dan bertahan dalam menunjukkan pula kepribadian suatau masyarakat.

Salah satu desentralisasi pendidikan di antaranya berupa desentralisasi kurikulum. Kementerian Pendidikan dan nasional menentukan berbagai standar yang minimal harus ada terpenuhi oleh satuan pendidikan khususnya di tingkat daerah atau lokal. Standar minimal itu berupa standar kompetensi lulusan, isi, evaluasi, serta standar sarana prasarana. Pengembangan selanjutnya terhadap berbagai standar tersebut diberikan kepada daerahnya masing-masing. Dengan kebijakan standar itu, maka masing-masing daerah atau lokal bisa meningkatkan potensi keunggulan wilayahnya yang sesuai dengan kondisi serta situasi setempat. Di antara kebijakan yang dapat dikembangkan tersebut yaitu membuat kurikulum sekolah berbasis kearifan lokal atau keunggulan lokal.

Kearifan lokal juga menjadi bagian dari budaya dalam suatu masyarakat yang sulit dipisahkan dari bahasa masyarakatnya. Kearifan atau budaya lokal sebagai suatu wawasan ilmu yang ditemukan oleh suatu masyarakat lokal tentunya melalui kumpulan beragam pengalaman dalam mencoba sekaligus dipadukan dengan penguasaan pemahaman terhadap budaya maupun keadaan alam dari suatu tempat daerah 
atau lokal tersebut (Padmanugraha, 2010, p. 12).

Dahana (Kompas, 28-11-2013) dalam sebuah artikel berjudul "Menyoroti ihwal generasi digital". Dalam tulisan mengatakan bahwa terdapat pada generasi baru yang hidup dalam warga masyarakat sekarang ini, yaitu generasi yang diistilahkan dengan generasi digital. Generasi di mana mereka lahir pasca tahun 1995 yang dikenal olehnya sebagai generasi $\mathrm{Z}$. Sebuah angkatan generasi baru yang tidak mudah diubah oleh percepatan berpikir kritis, tetapi juga mampu mengubah disetiap dimensi kehidupan. Bukan sekedar cara pandang atau paradigm hidup, cara berpikir, kosmologi, namun cara menatap cita-cita masa lalu maupun masa depannya sendiri. Generasi ini tidak lain merupakan dampak dari globalisasi tanpa sekat pemisah jarak.

Arus teknologi maupun informasi telah merubah sekat-sekat kebudayaan. Gelombang besar juga yang terdapat pada teknologi dan informasi bukan hanya sekadar melintasi batasan kebudayaan, melainkan dapat menghilangkan identitas kebangsaan. Identitas manusia merupakan bagian dari suatu anggota masyarakat juga tidak kuasa dipertahankan dari perubahan jati diri karakteristiknya. Perubahan yang mengakibatkan gejolak mental dan watak menjadi dampak dari perubahan budaya yang ada dalam daerah lokal tersebut.

Dunia baru menawarkan peradaban masa kini yang sementara akan berhasil mengajarkan pragmatisme, atau kehidupan sementara yang serba praktis dan cepat saji (Naufal, 2014; Idi, 2014; dan Rif'an, 2012).

\section{Pendidikan Kearifan Lokal}

Kearifan lokal yang sering dikenal dengan local wisdom bisa mengerti sebagai kegiatan manusia dengan mengoptimalkan akal budinya (kognitif) agar berperilaku dan bersikap terhadap peristiwa atau sesuatu objek yang berlaku dalam ruang tertentu. Pengertian tersebut dirancang secara etimologi, sehingga istilah wisdom dipahami sebagai ketrampilan individu orang dalam memanfaatkan akal pikirnya dalam bersikap bahkan bertindak menjadi hasil penilaian akan suatu hal, peristiwa atau objek tertentu yang terjadi. Sebagai sebuah pengertian wisdom juga dimaksudkan sebagai kearifan atau sebagai kebijaksanaan yang diyakini (Ridwan, 2007, pp. 2-3).

Kearifan lokal menjadi bentuk dialektika antara manusia dengan pengetahuan kehidupannya. Pengetahuan terambil dari kehidupan manusia di mana mereka berada, berikutnya direfleksikan untuk membantu manusia mengartikan makna kehidupan. Sebagai pedoman masyarakat yang selanjutnya kearifan lokal memberikan panduan yang jelas kepada berbagai ranah yang mampu dijangkau oleh perilaku atau tingkah laku manusia itu sendiri. Dalam proses terjadinya kearifan lokal tidak terlepas dari konsepsi secara individu, namun membutuhkan peran saling mengkomunikasikan yakni berupa masyarakat.

Nilai suatu kebudayaan merupakan lapisan abstrak nan luas ruang lingkup tingkatannya, dalam tingkatan ini berupa ide gagasan yang mengkonsepsikan berbagai hal yang paling tinggi nilainya dalam berkehidupan. Suatu sistem akan nilai budaya berupa berbagai konsepsi yang tumbuh dalam pemikiran oleh sebagian besar umumnya warga masyarakat mengenal sesuatu yang 
dianggap bernilai dalam hidup. Oleh karenanya suatu sistem atas nilai kebudayaan sering berfungsi sebagai pedoman teratas bagi kelakuan masyarakat. Sistem kelakuan manusia atau masyarakat lain yang tingkatannya lebih nyata, seperti beraneka ragam aturan khusus, norma-norma, dan hokum yang semuanya juga berpedoman pada nilai budaya itu sendiri. Nilai budaya yang ada akan mendorong pembangunan, bersifat tahan penderitaan, berusaha dengan sekeras tenaga, toleran terhadap pendirian atau mempercayai orang lain, dan saling membantu atau gotong-royong (Koentjaraningrat, 1984, pp. 8-25).

Pendidik yang memiliki kearifan lokal yaitu guru yang mengajarkan kepada anak didik agar senantiasa dekat melekat dengan situasi yang konkrit dalam kehidupan sekitar mereka terima. Freire (Wagiran, 2010) menyatakan dengan dihadapkan pada masalah maupun situasi konkret yang terimanya, anak didik semakin semangat tertantang dan termotivasi untuk menanggapinya secara kritis dan tuntas. Hal tersebut sama dengan penjelasan Suwito (2008) yang mengemukakan bahwa beberapa pilar pendidikan yang berbasis pada kearifan lokal mencakup:

1) Membangun insan manusia berpendidikan yang berprinsip pada pengakuan eksistensi manusia sejak dalam buaian atau kandungan,

2) Pendidikan yang berbasis nilai kebenaran serta keluhuran budi, terhindar dari cara berpikir yang tidak terpuji dangrusa-grusu atau asalasalan waton sulaya,

3) Pendidikan mengembangkan ke ranah karakter moral, relegius spiritual (ranah afektif) bukan sekedar kognitif pengetahuan dan ranah psikomotorik, serta
4) Bersinergi kepada kebudayaan, pendidikan serta pariwisata yang perlu ditumbuhkan secara sinergis dalam pembelajaran yang berkarakter.

Kearifan lokal yang menjadi modal terbentuknya karakter luhur. Keluhuran watak suatu bangsa yang selalu bertindak dengan penuh kasih akan kesadaran, sikap diri, dan mawas diri. Kearifan lokal merupakan suatu wacana keagungan tata moral yang khas kedaerahan.

Usaha untuk peningkatan pendidikan kearifan lokal tidak akan terselenggara dengan sempurna tanpa keterlibatan masyarakat secara optimal. Keikutsertaan segala unsur dalam masyarakat dalam mengambil keputusan dan menjadi penyelenggara program pendidikan merupakan partisipasi yang sangat berharga. Berbagai wujud kearifan lokal yang menjadikan daya dukung bagi pengembangan dan terlaksananya pendidikan pada masyarakat diantaranya sebagai berikut:

1) Kearifan lokal dalam masyarakat yang berupa peraturan tertulis perihal wajiban belajar

2) Kearifan lokal agar mempertahankan keharmonisan hubungan antar sesama warga dan manusia masyarakat sekitar

3) Kearifan lokal yang terkait dengan seni.

4) Kearifan lokal menjadi sistem ajakan atau anjuran harapan (yang tidak tertulis), namun ditetapkan dalam pertemuan yang diikuti oleh berbagai unsur warga masyarakat supaya menumbuhkan kecerdasan warga

Kearifan lokal juga diartikan sebagai hasil karya akal budi, tabiat, perasaan mendalam, bentuk perangai, dan juga anjuran agar senantiasa memuliakan manusia. Penguasaan terhadap kearifan lokal selalu mengusung jiwa masyarakatnya semakin berbudi luhur dan bermartabat. Wagiran (2010) 
dalam merumuskan local wisdom sebagai berikut:

Local wisdom or local genious is the knowledge wicht acquired or discovered by lokal people through the accumulation of experiences in integrated and trials with the understanding of surrounding culture and nature. It is dynamic with function of connected local wisdom created and to the global condition and situation. Definisinya paling tidak menyimpulkan beberapa konsep: 1) kearifan lokal merupakan sebuah pengalaman yang panjang, kemudian diendapkan menjadi petunjuk perilaku manusia, 2) tidak luput dari lingkungan empunya, dan 3) bersifat dinamis, terbuka, lentur, dan selalu beradaptasi dengan zamannya. Konsep tersebut juga sekaligus memberikan bentuk bahwa kearifan lokal sering terkait dengan kehidupan seseorang beserta lingkungannya. Kearifan lokal terwujud sebagai filter iklim atau penjaga global yang melanda disisi kehidupan manusia.

Kearifan yaitu suatu proses sekaligus hasil budaya manusia, yang dikelola untuk mempertahankan kehidupan. Ini mirip juga apa digagas oleh Geertz (1973): Local genious is part of traditional, and culture basic with that deeply rooted in community that related and human life with human resources, source of economic, culture, laws, and security. There is can be looked as a tradition that related through farming programs, build house, livestock, etc.

Lebih lanjut gariskan bahwa karakteristik dari local wisdom, antara lain: 1) local wisdom appears to be simple, but often is comprehensive, and than elaborate, diverse, 2) It is adapted to local, environmental conditions, and cultural, 3) It is flexible and dynamic, 4) It is tuned to need activities of local people, 5) It corresponds with quantity or quality of available resources, and 6) It cloaks well with all changes.
Berdasarkan berbagai pengertian yang diuraikan di atas, bisa diperjelas bahwa kearifan lokal itu menjadi sebuah budaya kontekstual yang selalu bersumber dari kehidupan sesama manusia. Ketika berkehidupan itu mampu berubah, kearifan lokal juga mengiringi akan selalu berubah pula.

\section{Dasar Hukum dan Gagasan}

Gagasan perihal pendidikan yang berbasis kearifan lokal itu berawal dari sebuah gagasan yang diungkapkan oleh Jhon Naisbit (1990) yang selanjutnya dikembangkan dan direspon oleh sebagian para pakar sosial dengan pernyataanya: berpikir global serta ertindak lokal (thinks globaly acts localy). Maksudnya yaitu: bahwa masyarakat bisa mengambil pengalaman maupun pengetahuan apapun, dari suku serta bangsa manapun, akan tetapi dalam mewujudkannya dalam sebuah tindakan perilaku ketika seseorang berada di dalam suatu tempat, maka akan menyesuaikan dengan nilai atau norma dan budaya yang melekat di tempat tersebut.

Adanya keilmuan pengetahuan maupun wawasan yang bersifat global, pribadi perorangan akan mampu dengan mudah mengenali dan membaca terhadap suatu masalah dan sekaligus mampu memecahkannya. Maka seseorang juga perlu untuk berbekal diri yang banyak agar wawasan menjadi relatif leluasa dan luas.

Pendidikan yang bebasis kearifan lokal sebenarnya sebagai bentuk manifestasi dan refleksi dari Peraturan Pemerintah tahun 2005 Nomor 19 perihal Standar Nasional Pendidikan, ada pada pasal 17 khususnya ayat (1) menjelaskan tentang kurikilum pada tingkat satuan jenjang pendidikan SD sampai SMA, 
bahkan pada jenjang atau bentuk lain yang sederajat, kemudian dikembangkan sesuai dengan jenjang pada satuan lembaga pendidikan, potensi daerah, sosial budaya, dan juga peserta didiknya.

\section{Ruang Lingkup dari Kearifan Lokal}

Local wisdom atau kearifan local

bila dilihat dari jenisnya mampu diklasifikasikan menjadi 5 (lima) kategori, yaitu: pakaian, industri rumah tangga, makanan, pengobatan, serta teknik produksi. Klasifikasi ini kurang tepat bila masih banyak hal lain yang mungkin jauh lebih penting. Oleh karenanya kearifan lokal tidak bisa dikotak-kotak apalagi dibatasi. Kategorisasi tersebut lebih kompleks dengan yang dikemukakan oleh Wagiran, (2010), meliputi kerajinan tangan, pertanian, pengelolaan sumberdaya alam, pengobatan herbal, maupun lingkungan, makanan tradisional, perdagangan, seni budaya, agama dan budaya, bahasa daerah, serta philosophi. Ruang Lingkup kearifan lokal bisa juga dibagi delapan, yaitu: 1) norma-norma lokal yang diberdayakan, seperti kewajiaban, laku Jawa, serta pantangan, 2) tradisi maupun ritual masyarakat serta makna yang terkandung sebaliknya, 3) mitos, legenda, lagu-lagu rakyat, maupun ceritera rakyat yang sering mengandung pengajaran atau pesan moral tertentu yang hanya difahami oleh komunitas local tersebut, 4) data informasi maupun pengetahuan yang menyatu pada diri sesepuh tetua adat masyarakat, pemimpin adat spiritual, 5) kitab-kitab suci atau manuskrip yang dipercaya kebenarannya oleh warga masyarakat lokal, 6) beragam cara berkomunikasi lokal atau komunitas dalam memenuhi kehidupan keseharannya, 7) alat atau bahan yang dipakai untuk kebutuhan tertentu, terakhir 8) kondisi lingkungan alam atau sumberdaya alam yang biasa digunakan serta diberdayakan dalam penghidupan bermasyarakat.

Begitu juga terkait lingkup budaya dimensi fisik dari kearifan lokal berupa: upacara adat istiadat, Wisata alam, cagar budaya, transportasi tradisional, prasarana budaya, permainan tradisional, warisan budaya, pakaian adat, museum, Kesenian, lembaga budaya, desa budaya, kerajinan maupun kesenian, cerita rakyat, dolanan anak, serta wayang. Sumber kearifan lokal yang lain dapat juga berupa lingkaran hidup orang Jawa yang terdiri dari: upacara tingkeban, ngapati, mitoni, upacara kelahiran, puputan, sunatan, perkawinan, bahkan sampai kematian serta mendoakan mayit.

Berbagai macam nilai local wisdom di atas menjadi potensi peningkatan pendidikan dan pengajaran berbasis kearifan lokal kedaerahan yang selanjutnya dapat dijabarkan secara detail dan rinci kedalam berbagai butir nilai kehidupan. Sehingga dalam dunia pendidikan sangat perlu untuk segera merancang, menentukan model yang sesuai dan tepat guna untuk melakukan implementasi terhadap kearifan local yang sekaligus mampu menjadi penerang model pendidikan karakter yang bersifat humanis.

\section{Tujuan, Manfaat, dan Sumber Kearifan Lokal}

Tujuan pendidikan yang berbasis kearifan lokal yaitu sesuai dengan apa yang termaktub dalam Sistem Pendidikan Nasional dalam Undang-undang Nomor 20/2003 ada pada Pasal 3, menyatakan bahwa pendidikan nasional itu berfungsi untuk membentuk dan mengembangkan 
$\begin{array}{lll}\text { kemampuan } & \text { karakter dalam } \\ \text { mencerdaskan } & \text { kehidupan }\end{array}$ maupun peradaban yang bermartabat. Juga bertujuan menjadikan warga yang demokratis dan meningkatkan potensi peserta didik supaya menjadi insan yang bertakwa, beriman kepada Tuhan Yang Esa, berakhlak mulia, sehat, cakap, berilmu, kreatif, mandiri, serta bertanggung jawab.

Sedangkan manfaat pendidikan berbasis pada kearifan lokal, yaitu: 1) melahirkan generasi keturunan yang bermartabat serta kompeten, 2) merefleksikan beragam nilai kebudayaan, 3) berperan aktif dalam menumbuhkan karakter bangsa, 4) ikut terlibat demi terciptanya identitas diri bangsa, dan 5) ikut berperan andil dalam memberdayakan budaya bangsa.

Kearifan lokal yang terdapat dalam setiap daerah khususnya Jawa, karenanya daerah yang memiliki etika yang sangat diakui sebagai daerah yang kaya akan beragam kebudayaan. Etika Jawa terdapat tata nilai kehidupan akan kejawennya, seperti tata perilaku, norma, kebiasaan, keyakinan, konsepsi, dan berbagai simbol yang terdapat dalam kehidupan serta ada kebahasaan yang menjadikan prinsip hidup oleh warga masyarakat yang ada di Jawa. Terdapat dua kaidah atau prinsip hidup yang ada khususnya di Jawa yaitu hormat dan rukun. Setiap manusia yang hidup dan menjalankan kehidupannya akan selalu berusaha sesuai norma yang berlaku, maka mereka warga masyarakatnya akan lebih tentram dalam hidup kesehariannya. Dua kaidah itu sangat ungent untuk dijadikan sebagai prinsip dalam kehidupan orang Jawa. Prinsip etis tersebut akan mengarahkan peribadi masyarakatnya kepada keadaan psikologis yang berupa rasa tenang dalam batin, terbebas dari berbagai bentuk ketegangan emosional, yaitu potensi manusia, potensi agama, potensi budaya, potensi alam

\section{Fungsi Manajemen Pendidik Berbasis Kearifan lokal}

Menurut sudut ilmu sosial bahwa yang dimaksud fungsi adalah adanya karakteristik atau perilaku tertentu yang menyeleksi suatu tugas tertentu dengan tugas yang lain, sehingga fungsi dan peran suatu pekerjaan akan menggambarkan terhadap warna tersendiri sebagai persyaratan proses penyediaan prasarana dan sarana yang dibutuhkan untuk menyempurnakan aktivitas tersebut (Atmodiwirio, 2001, pp. 12-13). Jadi fungsi adalah tugas pokok yang dilaksanakan untuk menyelesaikan kegiatan. Dalam manajemen, fungsi adalah sebuah tugas khusus yang dikerjakan sendiri (Siagian, 2014, p. 101).

Pidarta (2011, p. 4) menguraikan fungsi manajemen dengan berbagai ragamnya terdiri: merencanakan, mengorganisasikan, mengarahkan, menyusun staf, mengkoordinasi dan mengontrol, melaporkan dengan mencatat, serta sekaligus menyusun rancangan dan laporan anggaran belanja. Berikutnya dibuat lebih sedehana yang meliputi: merencanakan, kemudian mengorganisasikan, mengkoordinasi, memberi komando, dan mengontrol.

Sementara (Handoko, 2012, p. 23) menjelaskan bahwa fungsi manjemen yang paling penting itu ada lima, yaitu: planning, kemudian organizing, staffing, lalu leading, dan controlling. Selanjutnya Winardi menyatakan bahwa beberapa fungsi dasar manajemen di antaranya mencakup: perencanaan atau planning, kemudian pengorganisasian (organizing), dan pergerakkan (actuating), serta pengawasan (controlling) (Winardi, 2000, p. 63). 
Sedangkan George R Terry menjelaskan, bahwa fungsi manajemen itu berupa: planning, kemudian organizing, dan actuating serta controlling (Manullang, 2005, p. 19).

Teori ini digunakan untuk memperjelas keterangan dari penulis yang akan disusun sebagai berikut:

\section{Planning Pendidik}

Perencanaan pendidik pada dasarnya terjadi pada setiap tipe kegiatan, perencanaan pendidik merupakan proses dasar menentukan tujuan dan bagaimana cara meraih keinginan dirinya..

Planning atau perencanaan pendidik adalah menghubunghubungkan dan memilih kenyataan yang dihayalkan serta merumuskan berbagai langkah yang perlu untuk mendapatkan hasil yang diinginkan. Planning (perencanaan) pendidik sebagai formulasi tindakan masa mendatang difokuskan kepada tujuan yang hendak diraih oleh pendidik (Zaini Muchtarom, 1997, p. 38). Tegasnya sebagaimana diungkapkan bahwa perencanaan menentukan apa yang seharus diraih (penetapan waktu secara kuantitatif) dan jika hal itu hendak dicapai, maka hal itu harus diraih dengan siapa yang berkewajiban, dan mengapa hal tersebut harus diperoleh (Manullang, 2005, p. 48).

Selain itu, planning pendidik juga dapat berarti sebagai keseluruhan proses penentuan dan pemikiran secara matang dari berbagai hal yang hendak dilakukan di masa mendatang dalam rangka menciptakan tujuan pendidik yang ditetapkan (Handoko, 2012, p. 23). Perencanaan (planning) pendidik merupakan sesuatu aktivitas yang hendak diraih dengan proses dan cara, serta suatu orientasi masa mendatang, pengambilan keputusan, kemudian rumusan beragam masalah secara formal dan jelas (Wirojoedo, 1985, p. 6).
Jadi perencanaan Pendidik adalah memilih kegiatan serta menetapkan perihal yang hendak dikerjakan. Perencanaan yang baik mampu diraih dengan mempertimbangkan situasi serta kondisi di waktu mendatang. Dari pengertian tersebut, bisa dijelaskan bahwa perencanaan menjadikan suatu proses yang menyiapkan seperangkat alternatif bagi program masa depan yang diarahakan kepada perolehan tujuan dengan upaya yang maksimal atau optimal dan mempertimbangkan berbagai kenyataan hasil yang nyata di aspek sosial, ekonomi, budaya secara menyeluruh bagi pendidik.

\section{Organizing Pendidik}

Mengorganisasikan pendidik menjadi fungsi penting bagi organik manajemen atau administrasi pendidikan. Keutuhan proses pengelompokkan banyak orang, tugas-tugas, alat-alat, wewenang dan kewajiban sedemikian rupa akhirnya tercipta suatu individu pendidik yang bisa digerakkan sebagai kesatuan terpadu dalam rangka meraih tujuan yang dikehendaki (Siagian, 2014, p. 116). Untuk memahami hakikat dari pada pendidik, perlu diberikan pemahaman tentang organisasi pendidik.

Mengorganisasikan merupakan proses mengatur mendistribusikan pekerjaan, sumber daya antar pekerja atau anggota organisasi, wewenang, sehingga mereka bisa mencapai sasaran satuan pendidikan atau organisasi (James Stoner, 1996, p. 11). Pengorganisasian yaitu tindakan mengupayakan hubungan perbuatan yang secara efektif di antara beberapa orang, hingga mereka bisa bekerja sama dengan efisien serta memperoleh kepuasan individu dalam hal menjalankan berbagai tugas khusus dalam keadaan lingkungan tertentu guna meraih sasaran atau 
tujuan tertentu (Winardi, 2000, p. 217).

Organisasi pendidik berfungsi sebagai prasarana atau alat dari manajemen pendidik guna meraih tujuan yang ditetapkan, maka terhadap organisasi dapat diadakan peninjauan dari dua aspek. Pertama aspek organisasi sebagai wadah daripada sekelompok individu bersama-sama bekerja, dan aspek yang kedua organisasi sebagai proses dari pengelompokan manusia ke dalam satuan kerja yang efisien (Soedjadi, 1995, p. 17). Dengan demikian pengorganisasian bisa berarti sebuah proses dimana pekerjaan yang akan diberikan dalam beberapa komponen yang mampu ditangani, dan aktivitas mengkoordinasi berbagai hasil yang dicapai guna meraih tujuan tertentu (winardi, 2000, p 375).

Dalam buku lain dijelaskan, organizing (pengorganisasian) pendidik sebagai upaya untuk mempertimbangkan tentang susunan organisasi diri, pembagian tugas, pembagian tanggung jawab, dan berbagai hal yang apabila dilakukan dengan seksama akan menjamin efisiensi penggunaan kinerja pendidik (Muhtarom, 1997, pp. 38-39).

\section{Actuating atau Motivating (menggerakkan) Pendidik}

Bahwa keberhasilan suatu individu dalam usaha meraih tujuannya lebih banyak diputuskan oleh penguasaan diri. Pemimpin yang berhasil yaitu mereka yang sadar dan paham akan kekuatan dirinya yang paling relevan dengan perilakunya pada saat tertentu. Dia benar-benar memahami dirinya sendiri sebagai individu, dan kelompok, serta lingkungan sosial dimana mereka berada. Kemampuan untuk memotivasi atau mendorong, mengarahkan, mempengaruhi, dan berkomunikasi atau berinteraksi dengan bawahannya atau sekaligus pada dirinya sendiri yang hendak menetapkan efektifitas kinerja. Bagian pengembangan dan pengarahan organisasi diawali dengan memberi motivasi, karena para pimpinan tidak mampu menggerakkan kecuali kesiapan dirinya atau termotivasi agar bersedia mengikuti keinginannya (Admodiwiro, 2000, p.146).

Terry (2013, p. 15) menjelaskan dalam fungsi manajemen itu adanya planning, kemudian organizing, dan actuating, serta controlling. Actuating merupakan penggerakan peserta atau anggota kelompok dengan sebegitu rupa sehingga mereka berusaha dan berkeinginan untuk mencapai berbagai sasaran usaha yang dikehendaki. Artinya, perencanaan laksana penggerakan dan garis start yaitu bergeraknya mobil ke arah tujuan yang ingin diperoleh berbentuk garis finish, garis finish ini tidak akan dicapai tanpa wujudnya gerak mobil. Pemahaman tentang penggerakan telah dikembangkan menjadi 3 (tiga) pendekatan: pendekatan psikologis, pendekatan sosiologis, dan pendekatan perilaku.

\section{Controlling Pendidik}

Pengawasan atau controlling pendidik yang juga sering disebut dengan pengendalian pendidik yaitu beberapa fungsi manajemen yang berbentuk mengadakan koreksi sehingga hal yang sedang dikerjakan oleh dirinya mampu diarahkan kearah yang sesuai dengan maksud tercapainya tujuan yang ditetapkan sejak awal (Manullang, 2005, p. 23).

Lebih lanjut Stoner (dalam Admodiwiro, 2000, p. 12) memberikan pengertian bahwa pengawasan merupakan proses guna menetapkan bahwa pekerjaan sebenarnya cocok dengan kegiatan yang direncanakan. 
Control (pengawasan) pendidik berarti juga sebagai pengarahan atau perintah yang sesungguhnya, namun karena ditetapkan dalam peristilahan manajemen, control yang berarti memeriksa kemajuan penerapan apakah sesuai ataukah belum dengan rencana. Bila prestasinya mencukupi perihal apa yang diperlukan guna mencapai sasaran, serta yang bersangkutan tentu mengoreksinya (Michelon, 1986, p. 10). Menurut Handoko (2012, p. 354) pengawasan adalah menjadi proses berguna (menjamin) bahwa berbagai tujuan manajemen dan organisasi terwujud. Berbagai argumen yang telah terungkap di sini bisa disimpulkan bahwa pengawasan pendidik yaitu proses untuk menentukan, mewujudkan laporan yang lalu, menyeleksi standar, mengontrol kemajuan, mengambil tindakan, serta untuk menjamin tujuan diri. Sedang pengawasan pendidikan terkait hal ini ialah sebuah proses pengamatan yang bertujuan mengawasi pelaksanaan suatu program pendidikan. Baik hasilnya maupun kegiatannya semenjak permulaan hingga penutupan dengan cara mengumpulkan data-data secara terus menerus. Sehingga didapat sebuah bahan yang sesuai untuk diwujudkan dasar bagi proses perbaikan dan evaluasi yang prioritas, kelak bilamana diperlukan (Isa, 1994, p. 163).

Sistem pengawasan yang dipakai akan mempersembahkan banyak bahan yang sangat bermanfaat untuk mendapatkan fakta bagaimana suatu proses pengawasan dilaksanakan, dan sistem pengawasan itu terlaksana, untuk membimbing ataukah sematamata hanya alat untuk membuat-buat kelemahan atau kesalahan orang.

\section{KESIMPULAN}

Kearifan lokal yang berarti "kearifan akan budaya tradisional" suku-suku bangsa. Kearifan yang mengarah pada arti yang lebih luas tidak cukup sekedar berupa nilai-nilai dan norma-norma budaya. Kearifan lokal menjadi bagian dari kebudayaan suatu masyarakat daerah yang tak terpisahkan dari bahasa masyarakatnya. Kearifan lokal yang sering dikenal dengan local wisdom akan diteruskan secara berkelanjutan turun temurun berasal dari generasi nenek moyang melalui cerita dari lisan ke lisan. Keberadaannya ada di dalam cerita daerah atau rakyat, lagu, peribahasa, dan permainan rakyat daerah.

Pendidik yang berbasis kearifan lokal menjadikan pengajaran, pendidikan, serta pembelajaran kepada anak didik supaya anak lebih lekat dengan situasi yang konkret dari segala hal yang dihadapi. Pilar pendidikan terhadap kearifan lokal terdiri dari: 1) membangun peradaban manusia berpendidikan yang berdasarkan pada pengakuan eksistensi keberadaan manusia, 2) pendidikan bersumber atas kebenaran dan keluhuran budi pekerti, menjauhkan dari pemikiran yang tidak benar bahkan tindakan yang grusa-grusu atau waton sulaya (asal berdampak), 3) pendidikan yang mengarah kepada ranah moral (budi pekerti/akhlak mahmudah), kemudian spiritual (ranah afektif) bukan sekedar kognitif dan ranah psikomotorik belaka, dan 4) bersinergi kepada kebudayaan, pendidikan serta pariwisata perlu ditumbuhkan secara sinergis dalam pendidikan yang berkarakter nyata kedaerahan.

\section{DAFTAR PUSTAKA}

Ashlihah, N. (2016). Manajemen Guru dalam Pengelolaan Kelas Satu SD Muhammadiyah Wonogiri Tahun Pelajaran 2015/2016. IAIN Surakarta: Tesis. 
Atmodiwirio, S. (2001). Manajemen Pendidikan Indonesia. Jakarta: Ardadizya Jaya.

Dahana, R. P. (2012). Generasi Digital. Kompas. Minggu, 28 November 2012.

Geertz, Clifford. (1973). The Interpretation of Cultures. New York: Basic Books, Inc., Publishers..

Handoko, T. H. (2012). Manajemen. Yogyakarta: BPFE.

Isa, K. M. (1994). Manajemen Pendidikan Islam. Jakarta: Fikahati Aneska.

Koentjaraningrat. (1984). Kebudayaan, mentalitas, dan Pembangunan. Jakarta: Gramedia.

Manullang, M. (2005). Dasar-dasar Manajemen. Yogyakarta: Gadjah Mada Press.

Michelon, E. D, L.C. (1986). Metodemetode Managemen Moderen. Jambi: Andalas Putra.

Moleong, L. J. (2005). Metodologi Penelitian Kualitatif. Bandung: Remaja Rosdakarya.

Muchtarom, Z. (1997). Dasar-dasar Manajemen Dakwah. Yogyakarta: Al-Amin dan Ikfa.

Padmanugraha, A.S. (2010). Common Sense Outlook on Local Wisdom and Identity: A Contemporary Javanese Natives Experience. Paper Presented in International Conference on Local Wisdom for Character Building, Yogyakarta.

Pidarta, M. (2011). Manajemen Pendidikan Indonesia. Jakarta: Rineka Cipta.

Rahmawati, F. (2012). Manajemen Guru Pendidikan Agama Islam Sekolah Dasar; Studi Kasus Kelompok KKG PAI SD di Kecamatan Juwiring Kabupaten Klaten. UIN Yogyakarta: Tesis.
Rahyono. (2009). Kearifan Budaya Dalam Kata. Jakarta: Wedatama Widya Sastra.

Ridwan, N. (2007). Landasan Keilmuan Kearifan Lokal. Makalah dalam Jurnal Studi Islam dan Budaya Ibda'.Vol. 5. No. 1. Jan-Jun 2007. P. 27-38.

Rif'an, A. dkk.. (2012). Indonesia Hari Esok. Purwokerto: STAIN Press.

Rohman, Arif. (2009). Politik Ideologi Pendidikan. Yogyakarta: Laksbang Mediatama.

Siagian, S. P. (2014). Manajemen Sumber Daya Manusia. Jakarta: Bumi Aksara.

Soedjadi, F.X. (1995). $O \quad \& \quad M$ (Organization and methods) Penunjang Keberhasilan Proses Manajemen. Jakarta: Haji Masgung.

Stoner, J. A. F. (1996). Manajemen. Jakarta: Prenhallindo.

Suwito, Y. S. (2008). Pendidikan Berbasis Budaya Yogyakarta.

Makalah, Disampaikan dalam Sarasehan Budaya Selasa Wagen di Bangsal Kepatihan, 15 Juli 2008.

Terry, G. R. (2013). Prinsip-prinsip Manajemen. Jakarta: Bumi Aksara.

Wagiran, dkk. (2010). Pengembangan Model Pendidikan Kearifan Lokal di Wilayah Provinsi DIY dalam Mendukung Perwujudan Visi Pembangunan DIY menuju Tahun 2025 (Tahun Kedua). Penelitian. Yogyakarta: Biro Administrasi Pembangunan.

Winardi. (2000). Asas-asas Manajemen. Bandung: Mandar Maju.

Wirojoedo, S. (1985). Teori Perencanaan Pendidikan. Yogyakarta: Liberty. 